\title{
INCOME TAX GROUPING AS TAX MANAGEMENT TOOL: LESSONS FROM EU WITH FOCUS ON POLAND
}

\author{
Andrzej KARPOWICZ (D)* \\ Bialystok University of Technology, Management Engineering Faculty, Bialystok, Poland
}

Received 13 January 2020; accepted 29 April 2020

\begin{abstract}
The paper discusses the availability tax grouping among EU countries as well as benefits and costs of this tax incentive. Article focuses on Poland, where real usage of this tax management tool is analysed. Grounds for its (low) popularity are investigated. Analysis was made primarily based on observation of values and time trends build on data published by Polish Ministry of Finance, Statistical Yearbooks, PwC reports and Eurostat. Although tax grouping for corporate income tax purposes is offered by half of EU Member States, Poland is the only CEE country that offers this tax allowance. However, Polish corporations rarely use it in practice. Reasons include elevated entry requirements, lack of VAT grouping, low corporate income tax rate, lack of additional withholding tax benefits, no possibility of tax losses utilization, profitability requirements or retroactive duties in case of losing a status of a tax group. Those obstacles seem to outweigh the benefits of higher net return on capital, decreased transfer pricing requirements, higher liquidity and limited tax compliance burden. Those limited gains are prized primarily by biggest Polish entities, which indeed use tax grouping. The novelty and value of this paper lies in analysis of important topic from practical perspective, which was not thoroughly verified before both in Poland but also in other jurisdictions. It may also serve as a hint for managers considering entrance in a tax group and policymakers, while amending tax law regulations.
\end{abstract}

Keywords: income tax, tax management, taxation, return on equity, tax grouping, business tax.

JEL Classification: H21, H25, K34.

\section{Introduction}

Tax systems are of national character and hence vary among EU Member States. However, every single country belonging to this community imposes tax on profits of corporations. By default, governments tax income of every single entity independently - i.e. income tax is calculated and paid by individual companies. Such mechanism reflects the fact that any company enjoys legal personality and therefore could constitute a taxation subject.

Alternative scheme assumes group taxation. Although this solution is known for a century (when consolidation schemes were introduced in 1917 in US and later after World War I in Germany), to date only some jurisdictions allow for tax grouping for corporate income tax purposes (hereinafter: "CIT"). According to this latter idea income tax is paid by a body consisting of several related companies. Such tax group becomes a taxpayer. As a rule, under this method profit of particular legal entities forming a group is summed up and income tax is calculated and paid on such computed amount. From shareholder perspective who owns a number of related companies the latter scheme might be advantageous as it enables real time balancing and hence reduction of total CIT cost.

In the following sections I discuss the past research made which is relevant for group taxation. Then, I present data and its sources, which are then observed and interpreted in the article. Next I analyse the advantages and disadvantages of tax grouping from the prospective of shareholders. This is followed by overview of fiscal consolidation possibilities in EU Member States and discussion on the potential reasons for existence of tax grouping in particular countries. In successive chapters I analyse usage of tax grouping tool by Polish companies. Finally, factors that may influence decision to form a tax group are discussed and conclusions are made.

\section{Literature review}

The issue of tax grouping for CIT purposes did not draw much attention in scientific literature. Those limited studies that currently exist could be considered from three

*Corresponding author. E-mail: a.karpowicz@pb.edu.pl 
perspectives: (i) they focus on tax grouping in one state only, (ii) one (or few selected) advantages or disadvantages of tax grouping are analysed, or (iii) available research did not focus specifically on tax grouping, but appropriate findings might be relevant to this body of knowledge.

Weichenrieder and Mintz investigated the role of holding companies and conduit entities in German inbound and outbound FDI (Weichenrieder \& Mintz, 2008). They found that possibility of group consolidation is an important factor for the design of ownership chains. Their research suggests that availability of group taxation in a certain jurisdiction (according to local tax law) motivate investors to exploit that incentive and set up an umbrella company in that country. Concurrently, the attractiveness to establish a holding company abroad is reduced.

Oestreicher and Koch investigated determinants that influence decisions of companies on setting up a tax group under German CIT law (Oestreicher \& Koch, 2010). They found that just $30 \%$ of companies legally capable of forming a tax group decided to select this option. They noted that tax grouping is permissible for an entity holding directly or indirectly at least $50 \%$ of shares in the subsidiary. The same threshold applies to Austria. However, these are more liberal requirements than foreseen by most EU countries. For example, in Poland the ratio should be on $75 \%$ level (discussed further in this article), whereas Portugal demands 90\% engagement and Netherlands, France or Luxembourg expect $95 \%$ shareholding. In any case a tax group opting for registration should evidence that this threshold is met (as a rule such information on ownership structure is publicly available).

Gramlich, Limpaphayom, and Rhee (2004) who focused on Japanese companies acknowledge that so called Keiretsu firms, which are organized in groups, minimize their overall income tax burden by shifting profits among them. Consequently, they found that effective CIT rate of group companies is lower than observed among their independent counterparts. Eventually, this results in increased dividends paid out to shareholders (Gramlich et al., 2004).

Szlęzak-Matusewicz (2017) focused on Polish tax law. She highlighted inconsistency of Polish CIT law, which allows for tax grouping with local VAT act, that do not foresee such solution (Szlęzak-Matusewicz, 2017). This is unlike some other EU Member States were tax grouping for VAT purposes is allowed. Yet Hybka notes that just three countries among the European Union Member States apply the VAT grouping regime that is obligatory for the corporations fulfilling certain conditions (Hybka, 2019).

Asrul Hidayat claims that the main difference of corporate income tax regimes in Australia, Germany, and Indonesia consists is the ability to form a tax group in some of these jurisdictions (Hidayat, 2018).

Relatively low popularity of tax grouping might be connected with costs of tax grouping. For example Jung, B.Kim, and B. Kim, who concentrated on Korean market, claim that income shifting is used more extensively by listed companies than by the private ones (Jung et al.,
2009). Quoted entities are on average of larger size than privately held and hence they probably reap benefits from tax grouping more extensively. Although Jung et al. (2009) did not focus strictly on tax grouping, their finding is relevant also for tax grouping matters as income shifting is seen as key benefit of aggregation for tax purposes.

Researchers confirm that companies with different tax position belonging to a group shift income from those that are profitable to the loss-making (Scholes et al., 2014). Harris (1993) and Klassen et al. (1993) were among first who analysed this matter. They observed that multinational firms moved their profits to US after local tax system became more attractive with Tax Reform Act of 1986. Newberry and Dhaliwal evidenced that multinational companies use tax regimes in different countries to benefit from interest tax deductibility (Newberry \& Dhaliwal, 2001).

Yet income shifting issues in the past have been examined primarily on international level rather than within single jurisdiction (Gramlich et al., 2004). Such international focus was motivated by good research opportunities (Jung et al., 2009). As a rule within one jurisdiction the tax rate is the same for all taxpayers. This is not the case for cross-country analysis that use separate CIT rates. As a result, the drivers of income shifting at the level of companies are different. Scholes et al. (2014) note that existing literature provides related companies for several tax structuring hints in an environment where different tax rates are assigned to particular taxpayers.

Evidence suggests global foreign direct investment (hereinafter: "FDI") rise steadily along with the increased openness of national economies and decreasing CIT rates. This has been confirmed in several studies - for example in a research performed by Devereux and Griffith, who analyzed location decisions of US multinationals in four European countries in the period 1980-1994 (Devereux \& Griffith, 1998). The same results achieved Büttner and Ruf as well as Overesch and Wamser, who found that CIT rates influenced location decisions of German multinationals (Büttner \& Ruf, 2007; Overesch \& Wamser, 2010). Empirical studies confirm that the debt ratio is correlated with CIT rate in a way that CIT rate level in particular jurisdiction motivates companies to take more debt to make use of a tax shield in order to increase the net return of profit of international corporation as a whole (Desai et al., 2004; Mintz \& Weichenrieder, 2005; Büttner et al., 2006; Schwarz, 2009). Clausing, who analyzed intra-group trade of US international corporations found that a 10 percentage point lower CIT rate in a certain country results in drop of the price charged to the affiliate located in that state by 3-5 percent (Clausing, 2003). Concurrently, the affiliate charges for its export comparably more. These research is relevant for tax grouping as it suggests that effective tax rates (which are lower among tax groups than individual companies) are indeed considered by investors.

Dahle and Bäumer (2009) note that cross border loss-offset increase profitability of multinational companies. Ortmann and Sureth-Sloane acknowledge that such 
preference is particularly valuable for multinational corporations where high initial losses are followed by high profits, which is typical for start-ups or R\&D activities (Ortmann \& Sureth-Sloane, 2016). Although these research does not refer specifically to tax grouping, it is relevant here are it underlines importance of real time balancing of profits and losses, which is also offered by tax groups.

Büttner et al. (2008) focused on consolidation of firms under formula appointment. They noticed that the idea of formula appointment consists in consolidation of profit at the group level and then in its allocation to the companies forming such group. The idea of apportionment formula is elimination of profit shifting. However, they claimed that as long as not all related companies within a group are included in the system, the profit shifting incentive remains.

Tax neutrality is assumed to be preserved when total income is taxed in the state of residence, which should limit profit shifting (Hamada, 1966; Musgrave, 1969; Desai \& Hines, 2001). Otherwise entities are motivated to incur additional tax planning costs, which increase the deadweight loss (Musgrave, 1992; Feldstein, 1999). However, under residence based taxation companies may be tempted to locate in low-tax states (Mintz \& Weiner, 2003). At the same time countries may find that their tax revenues are at risk (Schreiber \& Führich, 2009). Tax grouping, which is a tax incentive of purely national character, does not put a threat of long-term tax base erosion and hence states should support this tool. Moreover, the risk of deadweight loss is limited.

Nicodeme blames lack of fiscal consolidation on EU level for suboptimal allocation of resources. He points that availability of tax grouping on country level may influence choice of tax residence as local losses may be deducted from domestic profits, whereas those incurred abroad are restricted (Nicodeme, 2006).

Dine and Koutsias underline that international tax grouping (in economic terms) is often abused and used for tax avoidance (Koutsias \& Dine, 2019). Cachia also puts attention to aggressive tax planning where tax grouping could be exploited (Cachia, 2017).

\section{Data sources and research methods}

The article provides for some basic information on group taxation in the EU. Information in this respect is sourced from European Commission and $\mathrm{PwC}$. Analysis is made on national level of particular countries. In addition, Common Consolidated Corporate Tax Base (hereinafter: "CCCTB") as a similar tool to tax grouping that could be introduced on EU level is discussed.

The main focus is laid on Poland. The motivation to select this country is twofold. On the one hand author has practical experience and in depth knowledge of Polish taxation system including tax grouping rules. More importantly, the access to good quality data enables empirical analysis.

All tax groups with Polish tax residence are obliged to publish their key financial results. The law that imposed these information requirements was introduced only in 2018. Yet it acts retroactively. Consequently, all such information is available from tax year ending in 2012. The newest data considered here is for 2017. Therefore, in most cases analysis made in this article concerns these six years. Obligatory reporting includes name of the taxpayer, tax year for which information is presented, data on revenues, income, income tax base and amount of CIT due.

Also all Polish individual taxpayers (companies), which revenues for a tax year exceed EUR $50 \mathrm{~m}$, need to publish their key financial data. Reporting period and data categories foreseen for publication are the same as in case of tax groups. Differences are: (i) tax groups are expected to release their financial data disregarding their earnings (i.e. all tax groups need to report), whereas (ii) single tax payers do not need to comply with these obligations, unless their revenue is below the mentioned threshold (consequently, vast majority of them is excluded from this burden).

As part of individual taxpayers also publish their financial data, there is a possibility to compare taxation duties of these two kinds of taxpayers.

There are also several advantages of the considered data from statistical reasons. Firstly, the data is limited to few categories, but comprehensive enough to provide for valuable results. Secondly, in case of tax groups whole population is embraced with no sampling. The available data is consistent among entities and over time as prepared following same legal rules binding in one state. It should be also reliable as required from taxpayers by rule of law and the data need to match results provided in annual tax returns. Finally, information for all taxpayers and years considered is generally complete (only minor information is missing). Hence, no imputation is required.

The data mentioned above is downloaded from Polish Ministry of Finance.

The other key source of data used in this article are Statistical Yearbooks of the Republic of Poland, which provide information on quantity of Polish companies. These data are used less extensively. However, the overall statistical quality of the figures should be also appreciated.

Research methods used in this article are forced by character of analysed issue. Therefore, various data are used in order to build graphs and to interpret the findings based on expertise of the author. Although modelling of the data may seem to be a good tool for analysis this is actually not the case - mainly due to small quantity of the sample and low variability of potential variables.

\section{Tax grouping as a tax allowance}

Fiscal function of taxes is commonly seen as the most important. Entities using tax grouping are likely to pay less income tax. The amount of CIT saved by shareholders equals the amount of revenue surrendered by a state budget. Therefore, the question arises on reasons for introduction of such tax incentive by local governments to state laws. Some states offer group taxation as they anticipate 
larger inflows in the long run (as a result of tax base increase) (Kondrashova, 2016).

From the perspective of taxpayers there are several issues related to tax grouping that should be considered. Firstly, tax consolidation may mean for companies' shareholders a valuable cash tax incentive. Immediate offset of tax losses is seen as key advantage offered by tax groups. Researchers confirm that lack of availability of loss-offset discourage investment (Auerbach \& Poterba, 1987).

Jung et al. observe that tax rate reduction implies less income shifting (Jung et al., 2009). Based on this finding they conclude that transfer of profits among related companies seems to be primarily tax motivated rather than a consequence of pure income management. Thus, tax grouping may be valuable allowance in high tax countries, where possibility to consolidate profits and losses in real time could significantly increase net return on equity invested.

The following common benefit of tax grouping are eased transfer pricing rules. Arms' length principle require that prices charged for goods or services between related companies that pay CIT on standalone basis are on market level. However, in several jurisdictions tax groups are free to conclude transactions that do not fulfil that principle. This is a significant easement for internal transactions. However, this issue has also negative consequences. Namely, the stakeholder of a company belonging to a tax group may have difficulty in assessment its true financial performance (Gramlich et al., 2004).

Tax groups usually face less compliance burden. This could be expressed in no requirement to prepare statutory transfer pricing documentation. In addition, tax group entities are often exempted from requirement to submit a tax return (as they are not single taxpayers). Only a representative company is expected to file a return. On the other hand tax grouping regulations in some jurisdictions are complex, which poses difficulties in their management and increases compliance burden to some extent (Ting, 2010).

Another benefit could consist in immediate profit transfer to the controlling company, which improves general cash flow of related companies (in opposition to dividend payments made typically once a year) (Prinz, 2003). Real time balancing of profits and costs of tax group companies also support overall liquidity.

Further advantages - again depending on specific jurisdiction - include tax savings with respect to no withholding tax on interest attributed to the representative company. There might be also transfer of tax savings (useful in case of debt financing) or comprehensive deductibility of participation related expenses (Oestreicher \& Koch, 2010). However, some of these benefits - especially with respect to no withholding tax on interest or dividend distribution - have become widely available for most individual EU companies based on EU tax directives.

There could be also other advantages of tax grouping, not directly related to tax issues. As evidence shows closely related entities typically are less exposed to bankruptcy or suffer smaller agency costs (Gramlich et al., 2004).

There are also disadvantages of tax grouping. They may include a requirement to set a tax group for a specific period of time with limited possibilities to resolve it before maturity. Hence, there is some lack of flexibility. Local laws usually demand high share capital level, which may induce freeze of money. Commonly there are strict shareholding engagements, which is demanding and restricts restructurings, even if desirable from business reasons. Tax groups are often expected by tax authorities to earn income in every single year, which certainly results in continuous tax payments (in opposition of taxation of single companies, which are allowed not to make profit and hence not to pay CIT at times). Finally, as a tax group for CIT purposes is a separate taxpayer, tax losses incurred by independent companies in previous years cannot be utilised after those very same companies form a tax group. Thus, sometimes a valuable deferred tax asset is lost or at least becomes frozen for a period of time the tax group is summoned for.

\section{Group taxation in EU and future prospects}

Not all companies are offered with group taxation possibilities. This depends on a state they reside in. In case of EU twelve countries allow for consolidation of income. This means that only companies with are located in those jurisdictions may choose the preferred way of taxation (i.e. either on standalone basis or group taxation). Opting for tax grouping is treated in local tax systems as an allowance and is not obligatory for companies. Depending on requirements taxpayers may choose to use tax grouping or resign from it. Capital group is usually free to choose, which companies should form a tax group, while leaving some related entities beyond a tax group - even if legally they are eligible for consolidation.

There are four schemes available depending on jurisdiction:

- fiscal unity - existing for example in Netherlands - assumes the parent company is treated as if all revenues and costs were incurred on its level. Then intra group transactions are not considered for tax purposes,

- tax base consolidation - applied in most western EU countries (but including Poland) - allow to pool the results of the subsidiaries at the level of representative entity. In other words, each group member computes the taxable income on its own, which is subsequently summed up at the level of the parent,

- in four jurisdictions there is no formal consolidation of profits of companies for CIT purposes. However, according to the local laws with use of permitted tax schemes similar effect to tax grouping could be reached,

- the latter scheme assumes simply no tax grouping (Table 1).

It strikes that, except for Poland, CEE Member States do not allow for tax grouping. Countries located in the 
Table 1. Availability of group taxation for CIT purposes among EU Member States (source: author's elaboration on the basis of data included in PwC Worldwide Tax Summaries Corporate Taxes 2018/19 (PwC, 2018)

\begin{tabular}{|l|c|c|c|c|}
\hline \multicolumn{1}{|c|}{ Country } & $\begin{array}{c}\text { Statutory } \\
\text { CIT rate } \\
\text { in 2017 }\end{array}$ & $\begin{array}{c}\text { Avail- } \\
\text { ability } \\
\text { of group } \\
\text { taxation }\end{array}$ & $\begin{array}{c}\text { EATR } \\
\text { in 2017 }\end{array}$ & $\begin{array}{c}\text { Difference } \\
\text { between } \\
\text { statutory } \\
\text { CIT rate } \\
\text { and EATR }\end{array}$ \\
\hline Bulgaria & 10.0 & No & 9.0 & 1.0 \\
\hline Hungary & 10.8 & No & 11.1 & -0.3 \\
\hline Cyprus & 12.5 & Yes & 13.0 & -0.5 \\
\hline Lithuania & 15.0 & No & 13.6 & 1.4 \\
\hline Ireland & 12.5 & Impeded & 14.1 & -1.6 \\
\hline Latvia & 15.0 & No & 14.3 & 0.7 \\
\hline Romania & 16.0 & No & 14.7 & 1.3 \\
\hline Croatia & 20.0 & No & 14.8 & 5.2 \\
\hline Estonia & 20.0 & No & 15.7 & 4.3 \\
\hline Czech Republic & 22.0 & No & 16.7 & 5.3 \\
\hline Slovenia & 19.0 & No & 17.3 & 1.7 \\
\hline Poland & 19.0 & Yes & 17.5 & 1.5 \\
\hline Slovakia & 21.0 & No & 18.7 & 2.3 \\
\hline Sweden & 22.0 & Impeded & 19.4 & 2.6 \\
\hline Finland & 20.0 & Impeded & 19.5 & 0.5 \\
\hline Denmark & 25.0 & Yes & 20.0 & 5.0 \\
\hline Portugal & 29.5 & Yes & 20.0 & 9.5 \\
\hline United Kingdom & 19.0 & Impeded & 21.5 & -2.5 \\
\hline Netherlands & 25.0 & Yes & 22.5 & 2.5 \\
\hline Austria & 25.0 & Yes & 23.1 & 1.9 \\
\hline Italy & 27.8 & Yes & 23.5 & 4.3 \\
\hline Luxembourg & 27.1 & Yes & 23.7 & 3.4 \\
\hline Greece & 29.0 & No & 27.6 & 1.4 \\
\hline Germany & 30.2 & Yes & 28.8 & 1.4 \\
\hline Belgium & 34.0 & No & 29.3 & 4.7 \\
\hline Spain & 25.0 & Yes & 30.1 & -5.1 \\
\hline Malta & & 32.2 & 2.8 \\
\hline France & & 33.4 & 1.0 \\
\hline
\end{tabular}

north provide for some tools that may to some extent deliver similar results in terms of taxation of income. Finally, all jurisdictions from western part of EU (except for Belgium, where fiscal consolidation is not permitted (Beuselinck \& Deloof, 2014) provide for group taxation. It strikes that there is a linkage between the statutory tax rates in particular jurisdiction and availability of group taxation - i.e. countries that impose high CIT rates generally allow also for group taxation. Among high tax jurisdictions an exception is Belgium and Greece (however, in Greece the legally set CIT rate was in 2011 and 2012 only 20 percent, which would locate this state among jurisdictions that use average tax rates, whereas usually such countries restrict group taxation). On the other hand Member States, which apply low CIT rates tend to resign from tax grouping (Cyprus stands out; yet this complies with the general picture of Cyprus, that is believed to put particular attention to tax competition and hence may be inclined to use any available tools that support its rivalry for capital - for instance Cyprus is the only EU country, which grants full exemption for capital gains on non-share assets; it also allows for unlimited period of carrying forward losses).

Similar conclusions can be drawn with respect to Effective average tax rate (hereinafter: "EATR"). EATR unlike the statutory one, encompass information on the size of tax base. EATR is computed by applying some of the basic tax rules included in a tax law of particular country to a hypothetical investment. Unsurprisingly, EATR is similar in terms of its behaviour to statutory CIT rate values. The correlation coefficient is 0.92 . This linkage is well visible on the below Figure 1.

If indexes are assigned to availability of group taxation (0 for no availability, 1 for impeded availability and 2 for presence of such tool), the Pearson correlation with statutory CIT rate is 0.46 , whereas it rises to 0.5 if compared against EATR. The results are acceptable for macroeconomic data but may not be satisfactory. The reason is that such discrete index figures may take only three values

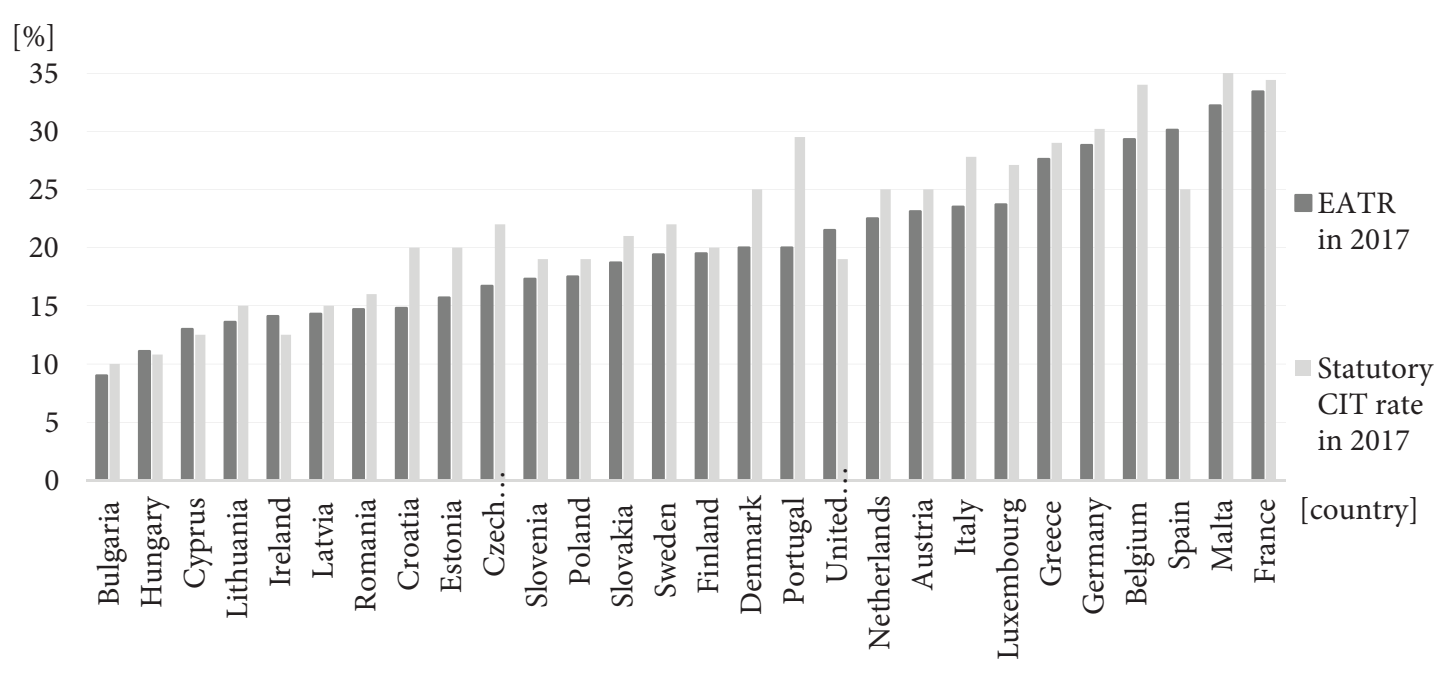

Figure 1. EATR and statutory CIT rates in EU Member States in 2017 (source: author's elaboration on the basis of data included in Eurostat and Taxation Trends in the European Union, 2018 Edition (European Comission, 2018)) 
and from mathematical perspective cannot fit perfectly the tax rates. The most interesting information from these calculation is the fact that such correlation coefficients are higher for EATR than for statutory tax rates (bearing in mind highlighted limitations).

Moreover, the correlation coefficient between (i) top statutory CIT rates and (ii) the difference between these rates and EATR is 0.39 . This suggests that high tax countries allow for more generous tax incentives. Tax grouping is one of available tools for reduction of nominal tax burden, whereas EATR does not take into consideration tax grouping. It seems that low tax EU Member States are less likely to further decrease the effective tax burden imposed on local taxpayers than their high tax counterparts.

Tax grouping discussed in this article is a tool of national nature. On international level in economic terms similar effect for taxpayers may produce CССТВ at this tool should provide for cross-border loss offset (similarly to tax groups, where fiscal consolidation occurs within one jurisdiction). Other advantages of СССТВ include also lesser compliance burden or more favourable transfer pricing regulations (Nicodeme, 2006). These are features typical also for national tax groups, which makes СССТВ a comparable instrument.

There is anxiety that consolidation of tax revenues of pan-European companies followed by tax income appointment between countries may harm some states though reduction of tax revenues (Schreiber \& Führich, 2009). Fuest et al. estimated that if CCCTB is introduced, tax base of larger EU economies will expand at the expense of smaller countries such as Belgium, Ireland, or the Netherlands (Fuest et al., 2006). Devereux and Loretz estimated that CIT revenues will generally decrease in EU but some countries (mostly new EU Member States) will gain (Devereux \& Loretz, 2007). Some other studies underlying unequal distribution of benefits and losses from СССТВ among EU countries were made also by other researchers (e.g. (Bettendorf et al., 2010; Nerudová \& Solilová, 2015). Thus, we have another similarity to a national tax group, where transfer of tax base occurs.

Appropriate tools should be introduced to eliminate any abuse of corporations artificially manipulating with the formula aiming to tax income in low tax EU country although earned in another state. Even if such threat would be managed, companies may still be inclined to invest primarily in low tax jurisdictions to pay less income tax overall. Any limits imposed on capital mobility result in tax-motivated investments. Such distortions are not in line with the idea of optimal taxation but some Member States support them in hope for higher fiscal revenues. The commonly used tool are controlled foreign company legislation or exit taxes, which curb capital mobility. Schreiber and Führich foresee that EU bodies may try to replenish exit tax in the future claiming that it violates freedom of movement of capital in single market (Schreiber \& Führich, 2009).

Profit shifting will not completely cease to exist as long as there are disparities in capital taxation among countries. However, such differences decrease along with the so called "race to the bottom" of the CIT rates (although some studies questioned the "race to the bottom" hypothesis (Quinn, 1997; Hays, 2003; Basinger \& Hallerberg, 2004). In practice the average CIT rate for EU Member States indeed decreased considerably from almost 35 percent in 1995 to less than 22 percent in 2017 (Karpowicz, 2018). CIT coordination among EU countries under СССТВ is not likely to stop the process of tax rate cuts. Therefore, Gorter and de Mooij argue that a minimum CIT rate for EU countries should be set (Gorter \& de Mooij, 2001). In their opinion this would allow Member States to maintain efficient capital taxation.

Oestreicher and Koch expect that mandatory CСCTB should reduce variations of CIT rates among Member States. On the contrary if CCCTB is optional for EU companies, EU countries will engage more in tax competition (Oestreicher \& Koch, 2008).

\section{General usage of tax grouping in Poland}

Investors acting in Poland rarely use tax groups (see Figure 2).

In 2012 there were only 28 tax groups in Poland. Their number increased over time (except for 2015 and 2016). In 2017 there were 69 tax groups, which is still an insignificant number for the total economy. The statistics on absolute numbers of tax groups may not be very informative. Therefore, on the below Figure 3 I present it in comparison to individual taxpayers.

In 2017 the share of tax groups in comparison to individual companies increased by $60 \%$ from 2012 to reach eventually $0.015 \%$. Thus, although tax grouping gradually got more attention among taxpayers, this is still a very niche tax incentive.

The above calculations are made based on the assumption that there are two companies in each tax group in every tax year, which is a minimum legal requirement. In practice there could be more companies in any tax group. However, such information is not publicly available. Nevertheless, even if the assumption would be made that each

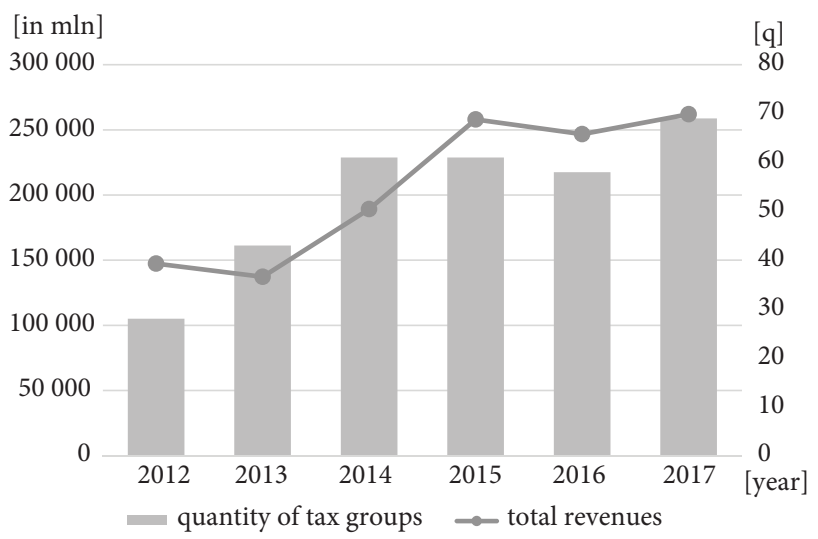

Figure 2. Number of tax groups in Poland and their total revenues (source: author's elaboration on the basis of data published by Polish Ministry of Finance) 


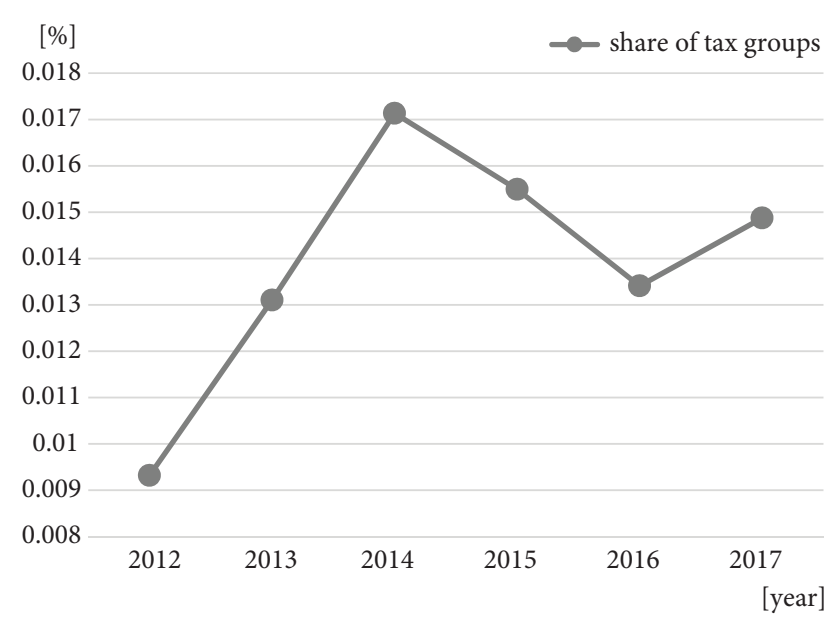

Figure 3. Tax groups as a share of all corporate taxpayers (source: author's elaboration on the basis of data from Statistical Yearbook of the Republic of Poland editions from 2018, 2015 and 2013 (Statistics Poland, 2018, 2015, 2013)

tax group is built on average of 20 companies (which in practice is very unlikely), that share for 2017 would not exceed $0.15 \%$. Another assumption made was that companies registered in Poland are Polish tax residents. There are reasons for such simplification. Firstly, there are no public data on number of Polish companies (or corporations registered abroad) being Polish tax residents. Secondly, in practice companies recorded in Polish National Court Register with high likelihood are concurrently Polish tax residents (whereas corporations registered abroad with high probability do not reside in Poland). This is due to the fact that according to Polish CIT law tax residency is agreed based on seat of a company or place of management. Summarizing, even if the above calculations would be biased to some minor extent, the key message - which is low usage of tax grouping in Poland - would certainly hold true.

As mentioned earlier the above calculations are done for the period ending in 2017. Yet, from 2018 the legal requirements for setting up and running a tax group were eased. In particular:

- Average share capital of each company included in a tax group should be at least PLN $0.5 \mathrm{~m}$ (i.e. half of the previous value),

- Share of income in the revenues should not be less than $2 \%$ (in opposition to $3 \%$ earlier requirement),

- Parent company need to hold in a subsidiary $75 \%$ of shares (whereas the previous requirement was 95\%).

These tax law amendments give hope that tax grouping will become more popular. However, mentioned alterations are not far reaching and limited solely to modifications of already existing economic or legal criteria.

Jung et al. conclude that there are always certain costs connected with income shifting (whereas income shifting opportunities are usually the key driver of tax grouping) (Jung et al., 2009). Such costs are both of tax and nontax nature. According to their research income shifting is more common among firms that have low non-tax costs than among those with high non-tax costs. In several situations net benefits of tax grouping may become questionable. In Poland costs of tax grouping in multiple matters also often exceed the winnings and chances for change of this parity in future years are minimal.

\section{Types of entities using tax grouping in Poland}

Taking into consideration the wording of Polish tax provisions, it seems that tax groups are foreseen especially for huge taxpayers. According to legal regulations binding in the period this article refers to, any tax group need to meet several requirements (as mentioned in previous paragraph). Conditions included in the Polish CIT act automatically eliminate:

- companies with low share capital,

- entities not organized in form of corporations (e.g. partnerships),

- companies with inadequate shareholding structure,

- low profitability companies,

- companies with tax arrears.

Small entities have difficulties to meet the criteria. The issue of high share capital requirement was already discussed in the previous paragraph. Smaller organization have less financing sources, including share capital.

Second requirement is also difficult to meet for small entities. Many of them by default do not have the status of corporation. Larger organisations often require both legal personality and limited liability and hence are organized in form of a company. As a result, they automatically satisfy this tax group entry condition.

As data presented on Figure 4 suggest, the share of companies is only a minor part of all income taxpayers active in Poland. Whereas in 2012 roughly $7.6 \%$ of entities enjoyed the status of corporation, this increased systematically up to $10.8 \%$ in 2017 . Still only one tenth of economic agents may even consider entering a tax group (disregarding other conditions mentioned here). Business activity run by individuals correspond to vast majority of



Figure 4. Quantity of entities registered in Poland (source: author's elaboration on the basis of data from Statistical Yearbook of the Republic of Poland editions from 2018, 2015 and 2013 (Statistics Poland, 2018, 2015, 2013) 
all entities active in Polish economy and by law their profits cannot be consolidated for CIT purposes.

Thirdly small businesses are often single, with no other related entities. Hence, they would not meet the requirement according to which there should be at least two related entities.

Fourthly, it may be also more challenging for small groups of entities to reach required profitability ratio in every single year of $3 \%$ or $2 \%$ (depending on fiscal year). Smaller groups consisting of few entities should have shallower income/loss balancing capacity than their big counterparts.

Finally, companies that want to form a tax group must not have any tax arrears. To meet this obligation appropriate liquidity is required. Among small entities with lower profitability this could be an issue. Moreover, small organizations are believed to have more difficulty in access to capital being a consequence of insufficient credibility or asymmetry of information among owners and lenders.

The fact that construction of tax law seems to be more adequate for business model of large entities is reflected in practice. In most years in the analysed period 2012-2017 number of tax groups increased but the general composition of tax groups has been changing. In particular, new-joiners in most cases are of smaller size than the tax groups set up in earlier years - which is depicted on Figure 5.

Along with the changes in quantity of tax groups, their total revenues usually followed that trend. However, that increase in earnings was less dynamic. Whereas in 2012 total revenues were PLN 147.3 bln, they reached PLN 262 bln in 2017 - almost $78 \%$ rise. At the same time number of tax groups increased by over 146\%. Hence, the quantity of tax groups rose two times faster than the overall inflows. This information suggests that recently primarily smaller groups of related entities joined the tax group scheme.

Indeed, seven out of ten biggest tax groups present in 2012 existed in each consecutive year. The position in the

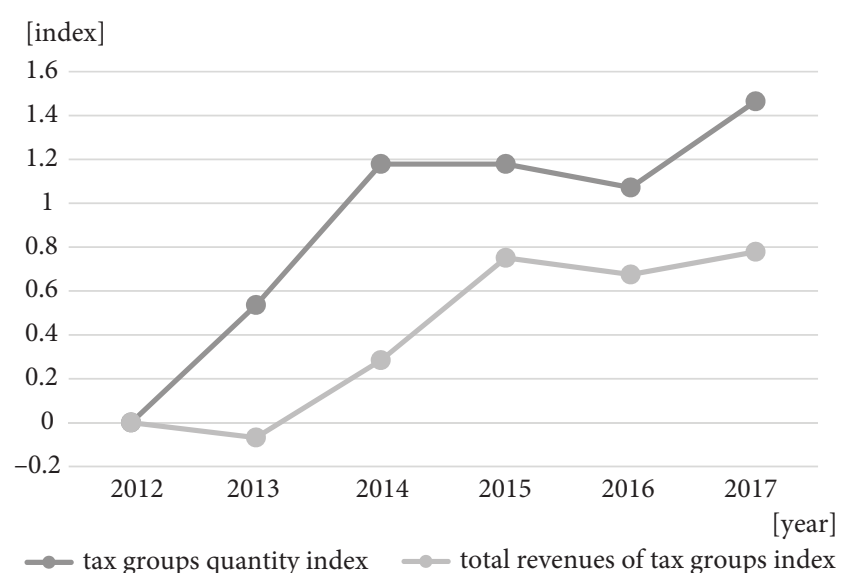

Figure 5. Total tax revenues of tax groups and their overall quantity (source: author's elaboration on the basis of data published by Polish Ministry of Finance) ranking of revenues each big tax group from this selection occupied has been changing. However, in every single year from the period 2012-2017 each big tax group reported earnings that gave it a position among top ten unions. They only switched positions among themselves. Thus, big taxpayers consequently use this incentive.

It appears, that taxpayers that have experience in using tax grouping, regard this allowance as an attractive tool. This claim is supported by the fact that among 28 tax groups existing in 2012 at least 15 of them enjoyed this scheme for not less than four years (out of six years considered in this article). This is interesting finding as according to Polish tax rules the standard term a tax group is summoned for is three tax years. Furthermore, this period can be interrupted by rule of law if certain conditions are not fulfilled. Thus, any tax group can resolve voluntarily after three years (or even earlier if conditions for its existence are breached). Consequently, after the requirements for existence of particular tax group expire, companies that formed it automatically become individual taxpayers. Yet, the quoted data confirm that over a half of entities building tax groups in 2012 willingly used this incentive for a period longer than standard. Therefore, we should assume that the same individual companies intentionally entered once more into a tax group (as they must have been satisfied with benefits this tax allowance brings).

Applicability of tax grouping for huge entities can be traced also from other perspective (please refer to Figure 6).

There were only eleven tax groups that existed for the whole analysed period (hereinafter: "established tax groups"). In 2012 they accounted for $39 \%$ of total number of all tax groups. However, at the same time their revenues built $82 \%$ of total revenues of all tax groups existing in that year. In the following periods the share of established tax groups in terms of quantity was generally falling to reach only $16 \%$ in 2017 . Concurrently, revenues they reported rose steadily to 2014 to reach $88 \%$ of earnings of all tax groups in total and then declined slightly to $79 \%$ in 2017.

[\%]

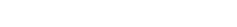

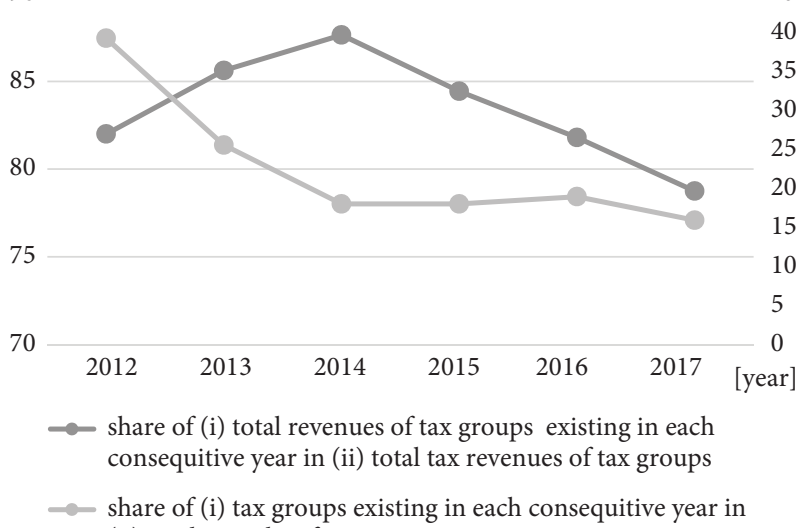

(ii) total numebr of tax groups

Figure 6. Revenues of established tax groups (source: author's elaboration on the basis of data published by Polish Ministry of Finance) 


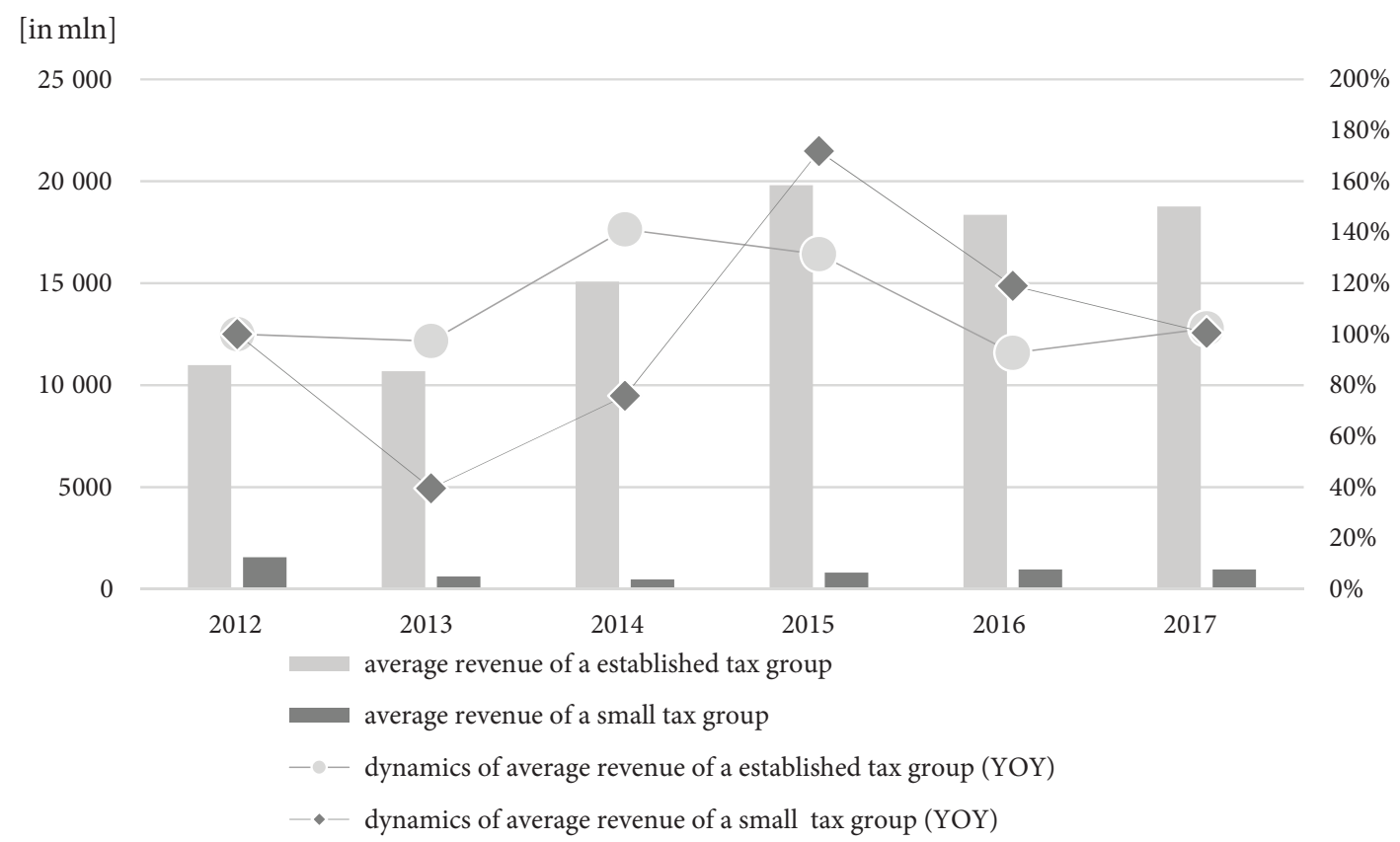

Figure 7. Average revenues of tax groups (source: author's elaboration on the basis of data published by Polish Ministry of Finance)

Summarizing, whereas year on year (with some approximation) there were less and less established tax groups in percentage terms, revenues they generated expressed as a share of total revenues remained relatively stable.

From Figure 7 we see that average revenue of established tax group in 2012 was almost PLN 10.98 bln and it was rising over most years. It peaked in 2015 with the value of PLN $19.8 \mathrm{bln}$. There was a slight decrease from 2015 to 2016 (mainly in connection with lower income reported by Polish Oil and Gas Company PGNiG) and further rebound in 2017. The remaining tax groups reported

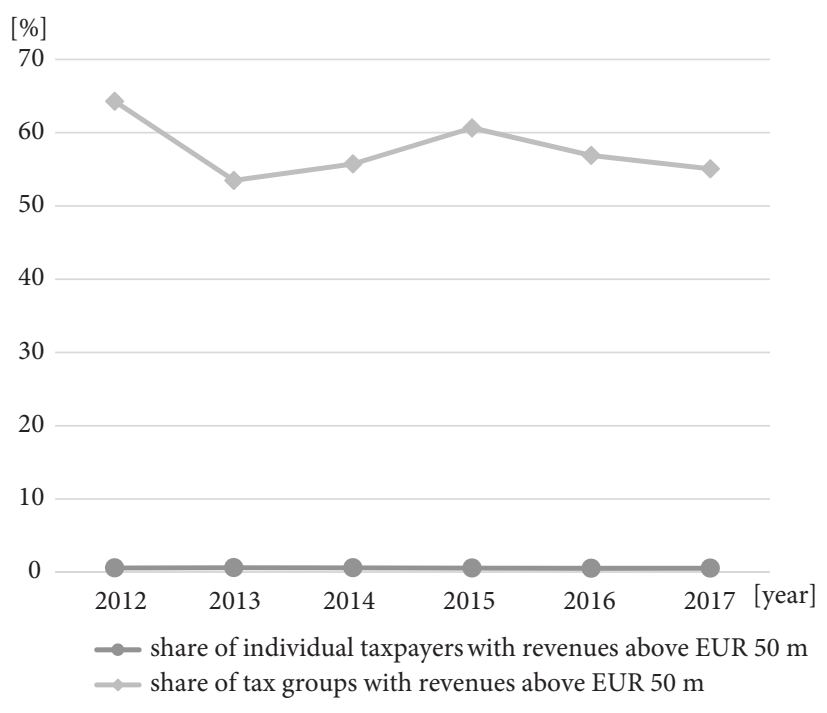

Figure 8. Share of taxpayers with revenues above PLN $50 \mathrm{~m}$ among (i) all individual companies and (ii) all tax groups (source: author's elaboration on the basis of data from Polish Ministry of Finance and Statistical Yearbook of the Republic of Poland editions from 2018, 2015 and 2013 (Statistics Poland, 2018, 2015, 2013) on average earnings of PLN 1.56 bln in 2012, with all-time low of PLN $470 \mathrm{~m}$ recorded in 2014. On average for the whole considered period established tax groups achieve inflows 20 time higher than their counterparts that existed only occasionally. The yearly volatility of revenues of smaller unions was also higher in comparison to established tax groups.

There is also one more evidence confirming the fact that tax grouping is especially tempting for large entities. $10 \%$ of tax groups with highest revenues in every single year from the time span 2012-2017 reached revenues that would give them a position among twenty individual Polish CIT-payers with highest earnings. Depending on the year there were only between 28 and 69 tax groups. Thus, $10 \%$ of them makes between 3 and 7 tax groups (rounded to the nearest integer). Concurrently, twenty independent taxpayers with highest revenues are only a small fraction of all single taxpayers. For example, in 2017 there were 2570 individual taxpayers with inflows above EUR $50 \mathrm{~m}$.

As Figure 8 suggests, among single taxpayers only a small share of companies could be regarded as large. Typically in the period $2012-2017$ only $0.58 \%$ of corporations revealed revenues above EUR $50 \mathrm{~m}$. This share is relatively stable and yearly changes are small. Concurrently, on average for the same time-span roughly $58 \%$ of tax groups earned not less than EUR $50 \mathrm{~m}$. Therefore, in case of tax groups the share of big taxpayers is 100 times higher than for companies that use single income taxation.

\section{Discussion of the results and conclusions}

Tax grouping is available in minority of EU Member States. Poland is the only positive exception in eastern part of the community. CССTB, if eventually introduced, would offer this tax incentive for entities in all jurisdictions. It 
is however uncertain, to what extent CCCTB would be exploited by taxpayers in practice.

Option of tax grouping for CIT purposes was introduced in Poland in 1996. Rules binding at that time were strict. Requirements were eased in the following years yet with no response from taxpayers. Before 2012 number of tax groups did not exceed 20. Slight increase observed recently was not triggered by tax law alterations. Polish CIT law facilitation with respect to requirements for running a tax group were introduced in 2001. In the following 17 years the CIT law in this respect stand still.

These are primarily big entities that use tax grouping in Poland. Top size groups seem to particularly price this tax incentive as they use it for more periods than an average tax union. Smaller organizations of entities join tax grouping occasionally or never. From this perspective CIT in Poland may be regarded as a regressive tax.

Typical obstacles small entities face include inadequate legal form, low profitability, lack of related entities, insufficient share capital or liquidity issues. However, year on year their share in terms of quantity increases. Probably this results from better awareness of tax law among their shareholders and attempts to increase net return on investment.

Investors seem to be reluctant to use tax grouping also due to costs of tax and non-tax nature. For example Oestreicher and Koch who focused on German market claim that fixed costs connected with tax grouping and liability risks deter from consolidation above all small entities (Oestreicher \& Koch, 2010). They found that the propensity to form a tax group falls with the decrease in size of the companies. These conclusions are applicable also for Poland.

Low CIT burden in Poland (especially in comparison to western or north-European countries) also does not support tax grouping. Benefit offered by this tax incentive in Poland is insignificant, as the companies are able to save on CIT only small values in comparison to taxation on standalone basis.

As noted earlier Polish law allows to carry forward losses available for future offset up to five years. As a result, tax losses constitute an asset of a company. Entities forming tax groups are able to compensate losses among themselves against profits in real time (which is certainly not possible for individual companies). Eventually, the only advantage of a tax group may become the ability to save on time value of money. Such benefit may not meet expectations of some corporations. Consequently, the propensity to form a tax group decreases.

In some jurisdictions tax groups provide for special withholding tax allowances. As in Poland rules in this respect are the same for all taxpayers, the incentive to form a tax group disappears.

Benefits of lower compliance burden are questionable. Taxpayers are rather afraid of premature loss of the status of a tax group, which would result in retroactive compliance burden and often will result in unexpected cash outflow.
Furthermore, Polish tax low does not foresee grouping for VAT purposes. Consequently, companies may be discouraged by the fact that the available solution is only partial (i.e. with CIT unity but without VAT consolidation).

Modified rules for establishment of tax groups are binning from 2018. It is interesting to what extent they will boost popularity of this tax incentive. As the changes are rather moderate no high response should be expected.

Summarizing, although tax grouping in Poland exists for almost a quarter of a century, there is still scope for further development of tax law in order to meet the expectations of management of local entities. Better awareness of tax grouping among investors may however increase the usage of this tax allowance.

\section{References}

Auerbach, A., \& Poterba, J. (1987). Tax loss carryforwards and corporate tax incentives. In M. Feldstein, The effects of taxation on capital accumulation, University of Chicago Press. https://doi.org/10.3386/w1863

Basinger, S. J., \& Hallerberg, M. (2004). Remodelling the competition for capital. How domestic politics erases the race to the bottom. American Political Science Review, 98(2), 261-276. https://doi.org/10.1017/S0003055404001133

Bettendorf, L., de Mooij, R., van der Horst, A., \& Vrijburg, H. (2010). Corporate tax consolidation and enhanced cooperation in the European Union. Fiscal Studies, 31(4), 453-479. https://doi.org/10.1111/j.1475-5890.2010.00121.x

Beuselinck, C., \& Deloof, M. (2014). Earnings management in business groups: tax incentives or expropriation concealment? The International Journal of Accounting, 49(1), 24-52. https://doi.org/10.1016/j.intacc.2014.01.008

Büttner, T., Riedel, N., \& Runkel, M. (2008). Strategic consolidation under formula apportionment. CESifo Working Paper 2484.

Büttner, T., \& Ruf, M. (2007). Tax incentives and the location of FDI: Evidence from a panel of German multinationals. International Tax and Public Finance, 14(2), 151-164. https://doi.org/10.1007/s10797-006-8721-5

Büttner, T., Overesch, M., Schreiber, U., \& Wamser, G. (2006). Taxation and capital structure choice - evidence from a panel of German multinationals. CESifo Working Paper, 1841. https://doi.org/10.2139/ssrn.935219

Cachia, F. (2017). Aggressive tax planning: an analysis from an EU perspective. EC Tax Review, Working Paper No 71 - 2017.

Clausing, K. A. (2003). Tax-motivated transfer pricing and US intrafirm trade prices. Journal of Public Economics, 87(9-10), 2207-2223. https://doi.org/10.1016/S0047-2727(02)00015-4

Dahle, C., \& Bäumer, M. (2009). Cross-border group-taxation and loss-offset in the EU: An analysis for CCCTB (Common Consolidated Corporate Tax Base) and ETAS (European Tax Allocation System). Arqus Quantitative Tax Research Discussion Paper. https://doi.org/10.2139/ssrn.2128991

Desai, M. A., Foley, F. C., \& Hines, J. R. (2004). A multinational perspective on capital structure choice and internal capital markets. The Journal of Finance, 59(6), 2451-2487. https://doi.org/10.1111/j.1540-6261.2004.00706.x

Desai, M. M., \& Hines, J. R. (2001). Foreign direct investment in a world of multiple taxes. NBER Working Paper, 8440. https://doi.org/10.3386/w8440 
Devereux, M. P., \& Griffith, R. (1998). Taxes and the location of production: evidence from a panel of US multinationals. Journal of Public Economics, 68(3), 335-367. https://doi.org/10.1016/S0047-2727(98)00014-0

Devereux, M., \& Loretz, S. (2007). The effects of EU formula apportionment on corporate tax revenues. Oxford University, Centre for Business Taxation.

European Comission. (2018). Taxation trends in the European Union.

Feldstein, M. (1999). Tax avoidance and the deadweight loss of the income tax. Review of Economics and Statistics, 81(4), 674-680. https://doi.org/10.1162/003465399558391

Fuest, C., Hemmelgarn, T., \& Ramb, F. (2006). How would formula apportionment in the EU affect the distribution and the size of the corporate tax base? An analysis based on German multinationals. Deutsche Bank, Discussion Paper No. 1: Economic Studies. https://doi.org/10.2139/ssrn.854909

Gorter, J., \& de Mooij, R. A. (2001). Capital income taxation in the European Union: trends and trade-offs. $C P B$ Special Publication. CPB Netherlands Bureau for Economic Policy Analysis.

Gramlich, J., Limpaphayom, P., \& Rhee, G. (2004). Taxes, keiretsu affiliation, and income shifting. Journal of Accounting and Economics, 37(2), 203-228.

https://doi.org/10.1016/j.jacceco.2003.10.001

Hamada, K. (1966). Strategic aspects of taxation of foreign investment income. The Quarterly Journal of Economics, 80(3), 361-375. https://doi.org/10.2307/1880725

Harris, D. (1993). The impact of US tax law revision on multinational corporations. Journal of Accounting Research, 31, 111-140. https://doi.org/10.2307/2491167

Hays, J. C. (2003). Globalization and capital taxation in consensus and majoritarian democracies. World Politics, 56(1), 79-113. https://doi.org/10.1353/wp.2004.0004

Hidayat, A. (2018). A comparative analysis of corporate tax group regime in Australia, Germany, and Indonesia. Simposium Nasional Keuangan Negara. Jakarta, Indonesia.

Hybka, M. M. (2019). German tax consolidation regimes in an international comparison. Journal of Management and Financial Sciences, 38 (September), 85-97.

Jung, K., Kim, B., \& Kim, B. (2009). Tax motivated income shifting and Korean business groups (Chaebol). Journal of Business Finance \& Accounting, 36(5-6), 552-586. https://doi.org/10.1111/j.1468-5957.2009.02141.x

Karpowicz, A. (2018). Why revenues from payroll taxes do not follow trends in taxation of income of corporations? 36th International Scientific Conference on Economic and Social Development - "Building Resilient Society". Zagreb, Croatia.

Klassen, K., Lang, M., \& Wolfson, M. (1993). Geographic income shifting by multinational corporations in response to tax rate changes. Studies on International Accounting, 131, 141-173. https://doi.org/10.2307/2491168

Kondrashova, N. (2016). Consolidated group of taxpayers: infusion into the Russian economic practice. International Journal of Economics and Financial Issues, 6(4), 1677-1683.

Koutsias, M., \& Dine, J. (2019). The three shades of tax avoidance of corporate groups: company law, ethics and the multiplicity of jurisdictions involved. European Business Law Review, 30(1), 149-181.

Mintz, J., \& Weichenrieder, A. J. (2005). Taxation and the financial structure of German Outbound FDI. CESifo Working Paper, 1612.

Mintz, J., \& Weiner, J. M. (2003). Exploring formula allocation for the European Union. International Tax and Public Finance, 10, 695-711. https://doi.org/10.1023/A:1026334005833
Musgrave, P. B. (1969). United States taxation of foreign investment income: issues and arguments. Law School of Harvard University.

Musgrave, R. A. (1992). Social contract, taxation and the standing of deadweight loss. Journal of Public Economics, 49(3), 369-381. https://doi.org/10.1016/0047-2727(92)90074-P

Nerudová, D., \& Solilová, V. (2015). The Impact of the CССТВ introduction on the distribution of the group tax bases across the EU: the study for the Czech Republic. Prague Economic Papers, 2015(6), 621-637. https://doi.org/10.18267/j.pep.514

Newberry, K., \& Dhaliwal, D. (2001). Cross-jurisdictional income shifting by U.S. multinationals: evidence from international bond offerings. Journal of Accounting Research, 39(3), 643-662. https://doi.org/10.1111/1475-679X.00032

Nicodeme, G. (2006). Corporate tax competition and coordination in the European Union: What do we know? Where do we stand? Munich Personal RePEc Archive.

Oestreicher, A., \& Koch, R. (2008). Corporate average tax rates under the CCCTB and possible methods for international loss-offset. SSRN Electronic Journal. https://doi.org/10.2139/ssrn.1456373

Oestreicher, A., \& Koch, R. (2010). The determinants of opting for the German group taxation regime with regard to taxes on corporate profits. Review of Managerial Science, 4, 119-147. https://doi.org/10.1007/s11846-009-0036-3

Ortmann, R., \& Sureth-Sloane, C. (2016). Can the CCCTB alleviate tax discrimination against loss-making European multinational groups? Journal of Business Economics, 86, 441-475. https://doi.org/10.1007/s11573-015-0780-6

Overesch, M., \& Wamser, G. (2010). The effects of company taxation in EU accession countries on German multinationals. Economics of Transition, 18(3), 429-457. https://doi.org/10.1111/j.1468-0351.2009.00385.x

Prinz, U. (2003). Wirtschaftliche Konsequenzen der Organschaft. Herzig N (Hrsg) Organschaft.

PwC. (2018). Woldwide Tax Summaries Corporate Taxes 2018/19.

Quinn, D. (1997). The correlates of change in international financial regulation. American Political Science Review, 91(3), 531-551. https://doi.org/10.2307/2952073

Scholes, M., Wolfson, M., Erickson, M., Hanlon, M., Maydew, E., \& Shevlin, T. (2014). Taxes and business strategy: A planning approach. Pearson.

Schreiber, U., \& Führich, G. (2009). European group taxation-the role of exit taxes. European Journal of Law and Economics, 27(3), 257-274. https://doi.org/10.1007/s10657-008-9090-6

Schwarz, P. (2009). Tax-avoidance strategies of American Multinationals: an empirical analysis. Managerial and Decision Economics, 30(8), 539-549. https://doi.org/10.1002/mde.1471

Statistics Poland. (2013). Statistical Yearbook of the Republic of Poland. Warsaw.

Statistics Poland. (2015). Statistical Yearbook of the Republic of Poland. Warsaw.

Statistics Poland. (2018). Statistical Yearbook of the Republic of Poland. Warsaw.

Szlęzak-Matusewicz, J. (2017). Podatkowa grupa kapitałowa na gruncie podatku od towarów i usług - ryzyko szacowania podstawy opodatkowania. Finanse, Rynki Finansowe, Ubezpieczenia. https://doi.org/10.18276/frfu.2017.3.87.2-05

Ting, A. (2010). Australia's consolidation regime: a road of no return? British Tax Review, (2).

Weichenrieder, A., \& Mintz, J. (2008). What determines the use of holding companies and ownership chains? Oxford University Centre for Business Taxation Working Paper. 